\title{
German-Polish scientific cooperations in divided Germany - Janusz Korczak associations in East and West Germany since the 1970s
}

\author{
Abstract \\ The Polish-Jewish paediatrician, pedagogue and writer Janusz Korczak \\ $(1878 / 79-1942)^{1}$ has not been honoured in Germany until many years after
}

1 Janusz Korczak (pseudonym) was born Henry Goldszmit in Warsaw in 1878/1879 the date of birth remained unclear - to an assimilated Jewish family in Warsaw, where he studied medicine (1898-1904) and subsequently worked at the Bersohn and Baumann Children's Hospital. From 1912 Korczak worked for 30 years as the director of a children's home (Dom Sierot) for Jewish orphans in Warsaw, where he introduced a new model of education, based on the concept of children's autonomy and self-government. In 1934 and 1936 Korczak travelled to Palestine and even thought about emigrating. With the German occupation in 1939, the living conditions for Korczak, his staff and the orphans were constantly deteriorating. In 1940 the entire orphanage was resettled in the Warsaw Ghetto. In August 1942, Korczak and his colleagues accompanied over 200 children to the Treblinka extermination camp, where they were murdered by the Nazis with poison gas. Korczak's literary work comprises 24 books and a large number of articles on multifaceted aspects of medicine, pedagogy, and literature. On the biography of Korczak cp. for example: Erich Dauzenroth, Ein Leben für Kinder. Janusz Korczak. Leben und Werk (Gütersloh: Gütersloher Verlagshaus, 2002); Lorenz Peter Johannsen, Janusz Korczak Kinderarzt, Jüdische Miniaturen, vol. 174 (Berlin: Hentrich \& Hentrich, 2015), 11-66; Michael Kirchner and Sabine Andresen and Kristina Schierbaum, Janusz Korczaks 'schöpferisches Nichtwissen' vom Kind, Beiträge zur Kindheitsforschung. Kinder, Kindheiten und Kindheitsforschung, vol. 11 (Wiesbaden: Springer, 2018), 7-15; Betty Jean Lifton, King of Children. The Life and Death of Janusz Korczak (London: Vallentine Mitchell, 2018); Hanna MortkowiczOlczakowa, Janusz Korczak. Arzt und Pädagoge, trans. Henryk Bereska (Weimar: Gustav Kiepenheuer, 1961); Wolfgang Pelzer, Janusz Korczak, 11 ${ }^{\text {th }}$ rev. ed. (Reinbek bei Hamburg: Rowohlt, 2012). 
his death in Treblinka in 1942. The German division led to the development of two separate German academic associations since the end of the 1970s, which aimed - under different political circumstances - to popularise and disseminate the memory of Korczak and his works. Both associations established personal and academic contacts and cooperations with the Polish Korczak Committee, whose history can be traced back to 1946, when contemporary witnesses of Korczak founded the Committee to honour Korczak's memory.

This paper aims to reconstruct the early scientific cooperations of both German Korczak associations with Polish scientists and the Polish Korczak Committee.

While in the Federal Republic of Germany (FRG) major research stimuli emanated at the faculties of education at Gießen and Wuppertal, in the German Democratic Republic (GDR) a first publicly perceived research focus crystallised at the only existing, state-controlled publishing house for schoolbooks (Volk und Wissen - Volkseigener Verlag) in EastBerlin. In the early 1980s, the work of the young associations was focused on biographical and bibliographical studies. Here it becomes obvious, that Korczak studies in East and West were substantially inspired and advanced by the then still living contemporary eyewitnesses of Korczak and their personal contacts to individual members of the existing Korczak associations. The history of the international Korczak bibliography is a characteristic example, that shows, how closely contemporary witnessing is linked to scientific research on Korczak.

Keywords: Janusz Korczak, cold war, German-Polish research cooperations, contemporary witnesses, memory studies.

\section{Introduction}

In 1982, the Polish professor of surgery Józef Bogusz (1904-1993)², who also worked on various aspects of the history and ethics of "Nazimedicine", characterised Janusz Korczak as "Pons Inter Nationes": In doing so, he cited Korczak as a symbolic "bridge" for the rapprochement

2 On the biography of Bogusz cf. Hamburger Institut für Sozialforschung, ed., Die Auschwitz-Hefte. Texte der polnischen Zeitschrift "Przegląd Lekarski" über historische, psychische und medizinische Aspekte des Lebens und Sterbens in Auschwitz (Weinheim and Basel: Beltz, 1987), 1:279. 
of peoples and peace. ${ }^{3}$ Bogusz considered the peaceful cooperation of Korczak researchers from different nations, as he had experienced at the International Korczak Symposium in Israel in 1981, to be a posthumous victory for Korczak. ${ }^{4}$ Until the recent past, this dictum has been frequently quoted in the context of Korczak research also in memory studies: in the noteworthy book on "Deutsch-Polnische Erinnerungsorte" (GermanPolish places of memory) in $2015^{5}$, which aims to describe and analyse the overlaps, interdependencies and asymmetries in the memory cultures of two neighbouring countries 6 , "Pons Inter Nationes" became the title of the essay dealing with Korczak ${ }^{7}$. While this essay focuses primarily on German-Polish artistic and popular representations, e.g. films, plays and sculptures, the present article shall focus on the German-Polish scientific cooperations in divided Germany. It is based on the initial insight into two, hitherto unexplored society legacies, which are described in more detail below.

3 Józef Bogusz, "Janusz Korczak - Brücke zwischen den Nationen," in Janusz Korczak. Zeugnisse einer lebendigen Pädagogik. Vierzig Jahre nach seinem Tod. Referate des Ersten Wuppertaler Korczak-Kolloquiums, ed. Friedhelm Beiner (Heinsberg: Agentur Dieck, 1982), 34-38.

4 Ibid., 37.

5 Hans Henning Hahn and Robert Traba, eds., Deutsch-Polnische Erinnerungsorte, vol. 1: Geteilt/Gemeinsam (Paderborn: Ferdinand Schöningh, 2015).

6 Hans Henning Hahn and Robert Traba, "Wovon die deutsch-polnischen Erinnerungsorte (nicht) erzählen," in Deutsch-Polnische Erinnerungsorte, ed. Hans Henning Hahn and Robert Traba, 11.

7 Nina Mueller and Gertrud Pickhan, "Pons inter nationes," in Deutsch-Polnische Erinnerungsorte, ed. Hans Henning Hahn and Robert Traba, 689-700. While Mueller and Pickhan focused primarily on German-Polish relations, Bogusz referred to a bridge between three nations: Poland, Germany, and also Israel. Cp. Janusz Bogusz, Janusz Korczak - Brücke zwischen den Nationen, 37. In the recent past, Korczak has also been metaphorically regarded as a bridge builder between generations but also between different disciplines, e.g. education and medicine. Cp. Kristina Schierbaum, Janusz Korczak, der Brückenbauer. Relektüre der Spannungsverhältnisse in seinem Leben und Werk (Wiesbaden: Springer 2018). 


\section{Korczak Collections travelled from \\ East to West and vice versa ${ }^{8}$}

Legacies of academic societies can offer an illuminating insight into the history of their work of science policy: Witnessed by unpublished correspondences and manuscripts as well as planning documents of conferences and publications, they shed light on the day-to-day work of responsible staff members, on organisational structures, on the internal and external social networking as well as on dynamics of power and hierarchies of the society concerned. ${ }^{9}$ In the case of the (West) German Korczak Society and the (East German) Janusz Korczak Research Team, the legacies of two founding members have been preserved. Access to the history of the German Korczak Society, is available in the scientific legacy of the first longstanding chairman Erich Dauzenroth (1931-2004). In the case of the Janusz Korczak Research Team, which was officially installed in 1980, unpublished papers of the research community were collected and preserved by the founding member Barbara Engemann-Reinhardt ${ }^{10}$ (1940-2019).

Significantly, the documents of the (East German) Janusz Korczak Research Team were archived in West-Germany at the University Library in Düsseldorf whereas the documents of the (West) German Korczak Society found its place in the Dedecius Archive at the Collegium Polonicum in Słubice at the German-Polish border. The whereabouts of the two legacies in question here are directly linked to the biographies of the donors. Their reciprocal migration contextualises the development of the two collections against the political background of the East-West system conflict during the Cold War.

8 This title is inspired by an essay of Engemann-Reinhardt: "Bücher auf dem Weg von Ost nach West. Das Korczak-Archiv in der Universitäts- und Landesbibliothek Düsseldorf,' in 'Das Paradies fanden wir...' Streifzüge durch die Bücherwelten der ULB Düsseldorf, ed. Irmgard Siebert (Frankfurt am Main: Vittorio Klostermann, 2017), 99-120.

9 Gisela Miller-Kipp, “Die Sammlung 'Janusz Korczak' der Universitäts- und Landesbibliothek Düsseldorf und ein Versuch, Janusz Korczak als 'Klassiker' der Pädagogik zu lesen," in Jahrbuch der Heinrich-Heine-Universität Düsseldorf 2007/2008, ed. Alfons Labisch (Düsseldorf: Düsseldorf University Press, 2008), 687-688.

10 In later years she added her maiden name to her surname, her earlier publications appeared only under the name Engemann. 


\section{The East-German Collection}

The estate of the Janusz Korczak Research Team followed the biographical path of Barbara Engemann-Reinhardt: Born in Berlin she studied German and Romance philology at the Humboldt University in Berlin (1958-1962) and worked as a teacher in Potsdam (1962-1968) before she became lecturer at the only existing publishing company for schoolbooks in the former German Democratic Republic (GDR), the Volk-und-Wissen Volkseigener Verlag Berlin (1969-1990), where she volunteered to disseminate Korczak's work in the GDR from 1973 onwards. Following the GermanGerman reunification she lost her job at the state-controlled VEB in 1990 and moved to West-Germany in 1998. There she met the Düsseldorf historian Kurt Düwell (born 1937) and the educational scientist, Gisela MillerKipp (born 1942), and decided to archive her collection in the immediate vicinity of her new place of residence. Previously, archiving had been considered at the Jewish Museum in Berlin. ${ }^{11}$ This comprehensive archive is to date one of the most extensive collection of material related to Korczak in Germany, and it contains not only primary and secondary Korczak literature, but also archive files, documents and personal testimonies, that shed light not only on the German but also on the international Korczak discourse. ${ }^{12}$ It includes archival documents that trace the founding of the International Janusz Korczak Association (IKA) (and its publication organ: Bulletin of the IKA) from the East-German perspective. In order to promote networking among the national Korczak societies, the Janusz Korczak International Newsletter was furthermore initiated by the Dutch Korczak Society in $1997 .{ }^{13}$

11 Barbara Engemann-Reinhardt, "Mein Weg mit Korczak - Berlin, Warschau und Düsseldorf," in Facettenreich im Fokus. Janusz Korczak und seine PädagogikHistorische und aktuelle Perspektiven, ed. Rosemarie Godel-Gaßner and Sabine Krehl (Jena: Edition Paideia, 2013), 33-48: 45-46; Rolf Willhardt, "Zwischen Pädagogik und Politik: Ausstellung in der Universitätsbibliothek zeigt KorczakArchiv," idw Informationsdienst Wissenschaft, January 1, 2005, https://idw-online. de/de/news96491.

12 Barbara Engemann-Reinhardt, "Bücher auf dem Weg von Ost nach West", 99-120; Gisela Miller-Kipp, “Die Sammlung 'Janusz Korczak' der Universitäts- und Landesbibliothek Düsseldorf”, 687-688.

13 Cp. Korczak Collection, Universitäts- und Landesbibliothek Düsseldorf (ULBD), Slg 15/Dok/23, unpaginated. 


\section{The West-German Collection}

Erich Dauzenroth, who was the chairman of the German Korczak Society for the first 12 years of its existence, donated his scientific legacy to the Karl Dedecius Archive, to date one of the largest collections on GermanPolish literary relations. ${ }^{14}$ This archive, which was established in 2001 in the Collegium Polonicum in Słubice, a joint institution of the European University Viadrina and the Adam Mickiewicz University of Poznań, contains the scientific legacy of the writer and translator of Polish literature Karl Dedecius (1921-2016), who himself was also often described as a "bridge builder between German and Polish culture". ${ }^{15}$ Born in Łódź, Dedecius was particularly committed to German-Polish relations in the context of European integration: To build up new networks of academic research on Poland, Dedecius founded the German Poland Institute in Darmstadt in 1980. ${ }^{16}$

The Karl Dedecius Archive became the centre of an extensive archive on German-Polish relations and to this day includes the estates of seven other "cultural mediators" between Germany and Poland, one of them is Erich Dauzenroth: Dauzenroth as well as the theologian Adolf Hampel (born 1933) ${ }^{17}$, another founding member of the German Korczak Society, was committed to the East-West dialogue, especially with Poland. For many years he was responsible forfor the partnership between the universities of Gießen and Łódź, which has been existing since 1978. ${ }^{18}$

14 Margarete Hager, "Das Karl Dedecius Archiv - Ein Projekt der Deutschen Forschungsgemeinschaft," Der Archivar 57 (2004): 231-234.

15 Anonymus, "Denkwürdige Rückkehr nach Frankfurt (Oder)," Märkische Oderzeitung, October 11, 2002. The metaphor of a cultural and linguistic bridge in the context of Dedecius' work was often used: Stefanie Peter, "Sprachbrücke: Dedecius-Archiv in Slubice eröffnet," Frankfurter Allgemeine Zeitung, October 21, 2002; Dietrich Schröder, "Über-Setzer ans andere Ufer der Sprache. Karl-Dedecius-Archiv der Viadrina eröffnet," Märkische Oderzeitung, October 11, 2002.

16 "Deutsches Polen Institut", accessed July 15, 2001, https:/www.deutsches-poleninstitut.de.

17 Ursula Hahn-Grimm, "Adolf Hampel - ein Pionier des Ost-West-Dialogs," Gießener Anzeiger, March 9, 2013, http:/www.giessener-anzeiger.de/lokales/kreis-giessen/ hungen/adolf-hampel--ein-pionier-des-ost-west-dialogs_12905748.htm.

18 Friedhelm Beiner, "Prof. Dr. Erich Dauzenroth †," Uni-Forum. Zeitung der JustusLiebig-Universität 17, no. 4 (2004) 4): 13. 


\section{Early research on Janusz Korczak in Poland}

Research on life and work of Janusz Korczak ${ }^{19}$, the Jewish-Polish paediatrician, educator and writer who was murdered in Treblinka in 1942, began in Poland shortly after the end of World War II. Eyewitnesses to his work as director of the Warsaw orphanage Dom Sierot for Jewish children (1912-1942), as advocate of children's rights, as reform pedagogue, as expert witness for educational issues at the district court, as editor and founder of a children's newspaper "Little Review" 20 and a radio programme ${ }^{21}$ commemorated different details of Korczak's life and work. Their personal memories of Korczak were inseparably interwoven with their individual perspective, whether they were a child, a trainee, a teacher or an educator in one of the two orphanages Korczak worked for. Other eyewitnesses of Korczak were journalists, secretaries, publisher or personal acquaintances, who came in contact with Korczak through his extensive literary work, which touches various literary genres on diverse topics ranging from pedagogy to medicine and everyday life. ${ }^{22}$ An example of the amalgamation of eyewitness testimony, personal recollection and incipient Korczak research is shown through the first Korczak biography, which appeared in Krakow in 1949. It was written by Hanna Mortkowicz-Olczakowa (1905-1968), who was the daughter of Korczak's publisher. ${ }^{23}$ Early Korczak research in Poland was largely shaped by the memories of contemporary witnesses, who founded the Committee to honour Korczak's memory in Warsaw as early as 1946. It became the predecessor organisation of the still existing Polish Association of Janusz Korczak, which changed its name several times. The target groups of their first works dealing with Korczak's pedagogical concepts were primarily educators and parents. ${ }^{24}$

19 On the biography of Korczak cp. footnote 1.

20 The Polish original title was "Mały Przegląd".

${ }^{21}$ Using the pen name "The Old Doctor" Korczak made interviews and broadcasts for children in the Polish radio.

22 On the extensive work of Korczak cf. Aleksander Lewin, Janusz Korczak Bibliografia 1896-1942, Bibliografię przygotowano w Zakładzie Spuścizny Pedagogicznej Janusza Korczaka Instytutu Badań Pedagogicznych w Warszawie. red. Marta Ciesielska (Heinsberg: Agentur Dieck, 1985), 81-172.

23 Hanna Mortkowicz-Olczakowa, Janusz Korczak (Kraków: Mortkowicz 1949).

24 Polskie Stowarzyszenie im. Janusza Korczaka, accessed July 15, 2021, http:/www. pskorczak.org.pl/strony/o_stowarzyszeniu.htm. 
While the Polish Commemoration of Korczak and his work started immediately after WW II, a broader Korczak reception in Germany developed only in the 1970s. It paved the way for the emergence of academic Korczak societies in both West and East Germany, whose explicite aim was to popularise and disseminate the memory of Korczak and his works. Both societies sought contact with their Polish colleagues in different ways.

\section{The memory of Korczak on both sides of the Berlin Wall}

The unexpected posthumous award of the Peace Prize to Janusz Korczak by the German Publishers and Booksellers Association (Börsenverein des Deutschen Buchhandels) in $19722^{25}$ played a decisive role in making Korczak known to the West and East German public.

However, the foundation board's decision in favour of Korczak led to a controversial debate: As Korczak had no descendants, the foundation board decided to give the prize money to the Polish Korczak Committee in Warsaw. This decision was immediately criticised by the Central Council of Jews in Germany in the light of increasing anti-Semitism in Poland since 1967. ${ }^{26}$ Hendrik van Dam (1906-1973), the Secretary General of the Central Council of Jews, pointed out that among the emigrated Polish Jews there was also a former member of the Polish Korczak Committee. ${ }^{27}$ This was the case of Michał Wróblewski, who had worked with Korczak in the years 1931-1942 and who was a founding member and chairman of the Polish Korczak Committee. Wróblewski emigrated from Poland to Sweden, where he founded the Swedish Korczak Association

25 Nina Mueller and Gertrud Pickhan, "Pons inter nationes", 692.

26 Under the pressure of an anti-Semitic campaign in Poland, about 13.000-15.000 Poles of Jewish origin emigrated in 1968-1971. Cp. Hans-Christian Dahlmann, "Die antisemitische Kampagne in Polen 1968," Jahrbücher für Geschichte Osteuropas. Neue Folge 56, no. 4 (2008) 554-570, 566. On the anti-Semitic propaganda in Poland see also Audrey Kichelewski, "Imagining 'the Jews' in Stalinist Poland: nationalists or cosmopolites?", European Review of History - Revue européenne d'histoire 17, no. 3 (June 2010): 505-522.

27 Cp. Hendrik van Dam to Werner Dodeshöner, May 26, 1972 and July 14, 1972, Stiftungsrat für den Friedenspreis, Archiv Friedenspreis des Deutschen Buchhandels, Berlin, Germany. 
in 1971.28 (Given the Baltic Sea focus of this special issue, it might be of interest that in Vilnius, Lithuania, the Januso Korcako Centres were founded). The controversial debate involved various actors and institutions and was essentially linked to the question of Korczak's personal identity as a Pole or as a Jew, which led to various appropriations. ${ }^{29}$ When the prize was finally awarded the President of the Association concluded "(...) we have not honoured a Pole, not a Jew with this prize, but a human being (...)" (trans. A. OH.). ${ }^{30}$

Mikołai Gliński has pointed out, that "paradoxically, the image, that Korczak was not a Jew, is still popular in today's society." 31

${ }^{28}$ Cp. The Janusz Korczak Living Heritage Association, accessed September 13, 2021, https://fcit.usf.edu/Holocaust/korczak/about.htm. Cp. Wróblewski's contribution to: Ergänzungsband Janusz Korczak in der Erinnerung von Zeitzeugen, ed. Friedhelm Beiner and Silvia Ungermann (Gütersloh: Gütersloher Verlagshaus 1999), 185-189, 334-338, 564.

Nowadays there are national Korczak societies in at least 27 different countries. Many of them were founded or at least inspired by Korczak eyewitnesses, who fled from Warsaw to different countries. A characteristic example is "The Society of friends of Dr. Janusz Korczak" which was founded by Stach Rozenberg (Stanley Robe) in Melbourne, Australia, in 1984. Cp. the childhood memories of a relative: Monika Sznajderman, Die Pfefferfälscher: Geschichte einer Familie, trans. Martin Pollack (Berlin: Jüdischer Verlag, 2018), 11; Alicja Szlązakowa. "Warsaw October," Bulletin of the Janusz Korczak International Association, January-June, July-December 1982, no. 5-6, 6.

29 Cp. Hendrik van Dam to Werner Dodeshöner, May 26, 1972: “Janusz Korczak ist (...) zu einem Märtyrer des Judentums geworden.”; Inge Kaufmann to Werner Dodeshöner, August 3, 1972: "Die Ehrung von Janusz Korczak ist eine Würdigung eines polnischen Menschen und wird auch in Polen so verstanden (...).”, Stiftungsrat für den Friedenspreis, Archiv Friedenspreis des Deutschen Buchhandels, Berlin, Germany.

30 Ernst Klett, "Friedenspreis 1972”, Börsenblatt für den Deutschen Buchhandel, Frankfurter Ausgabe, October 10, 1972, 2343: "Janusz Korczak war Pole jüdischer Herkunft, Jude polnischer Nationalität. (...) Gleichwohl haben wir nicht einen Polen, nicht einen Juden mit diesem Preis ausgezeichnet, sondern einen Menschen, eine außerordentliche, eine reine Gestalt, wie sie einem Jahrhundert nur selten geschenkt wird."

31 Mikołai Gliński, “12 Things Worth Knowing About Janusz Korczak” (September 16, 2016), accessed September 13, 2021, https://culture.pl/en/article/12-things-worth-knowing-about-janusz-korczak. 


\section{The (West-) German Korczak Society}

This controversial tribute to Korczak also facilitated the academic Korczak discourse that emerged through Dauzenroth's initiative at the Justus-Liebig-University of Gießen. There, the first International Korczak Symposium took place in 1973 and gathered Korczak experts from Austria, Germany, and Poland. At the University of Gießen, Korczak research was furthermore established at the Institute for "Educational Research and Pedagogy from Abroad" (trans. A. OH.), which was founded in 1974. ${ }^{32}$

In those early years, the scientific interest was mainly directed towards biographical work and Korczak bibliographies. ${ }^{33}$ This did not change with the founding of the Korczak Society in 1977. According to its Articles of Association (1977), this society pursues the promotion and preservation of the "scientific and literary legacy of Dr. Janusz Korczak also in cooperation with educational institutions bearing Korczak's name, and through the cooperation within an international network" 34 (trans. A.OH.). The aim of the Society's international networking was to further the understanding and reconciliation especially with Israel and Poland. The German Korczak Society became a member of the Janusz Korczak International Association, founded in 1978 in Warsaw. ${ }^{35}$ Dauzenroth was one of the founding members.

In the early 1980s, a second center of Korczak research emerged at the University of Wuppertal, where the educational scientist Friedhelm Beiner (born 1939) initiated an International Korczak-Kolloquium. ${ }^{36}$ Beiner eventually succeeded Dauzenroth as Chairman of the German Korczak Society.

From 1992 onwards the Society, initially twice a year, published a Korczak Bulletin with historical texts about Korczak and his pedagogy, as well as information on the national and international activities of

32 Justus-Liebig-Universität Gießen, “Ordnung des Instituts für Bildungsforschung und Pädagogik des Auslands der Justus-Liebig-Universität Gießen”, June 9, 1978, https:// www.uni-giessen.de/mug/2/pdf/61-04-2.pdf/view.

33 Erich Dauzenroth and Adolf Hampel, Giessener Korczak-Bibliographie (Gießen: Justus-Liebig-Universität 1980); Rainer Pörzgen, Janusz Korczak Bibliographie (München: K.G. Saur, 1982).

34 Siegfried Steiger, "Deutsche Korczak-Gesellschaft," in Handbuch Vereine der Reformpädagogik, ed. Maren Gronert and Alban Schraut (Baden-Baden: Ergon Verlag, 2018), 257.

35 Ibid., 257-258.

36 Friedhelm Beiner, ed., Janusz Korczak. Zeugnisse einer lebendigen Pädagogik. Korczak-Kolloquium. Vierzig Jahre nach seinem Tod (Heinsberg: Agentur Dieck, 1982). 
the Society. Since 1994 the Korczak Bulletin also includes societal information of the Austrian Janusz Korczak Society (founded in 1992) ${ }^{37}$ and the Swiss Korczak Society (founded in 1980) ${ }^{38}$.

\section{The (East-German) Janusz Korczak Research Team ${ }^{39}$}

In contrast, the founding of the Janusz Korczak Research Team in 1980 took place under completely different circumstances. On the occasion of the Korczak Year, proclaimed by the Polish government in 2012, one of the founding members of the Research Team, Barbara Engemann-Reinhardt, recalled the origin of this institution in the former GDR: ${ }^{40}$ At the beginning of the Korczak discourse in East Germany, which first was informal, stood the personal interest of the editor-in-chief Günter Schulze (1925-2010) and his assistant Barbara Engemann at the Volk-und-Wissen publishing house. ${ }^{41}$ Working at the publishing house facilitated their access to literature from the West. ${ }^{42}$ At the same time, the acceptance of their pedagogic and literary work by the Eastern Bloc countries was politically important. Thus, a reference to the introduction of the Russian edition of "How to love a child"

${ }^{37}$ Karl Garnitschnig, "Österreichische Janusz Korczak Gesellschaft. Das Recht des Kindes auf Achtung," in Handbuch Vereine der Reformpädagogik, ed. Maren Gronert and Alban Schraut (Baden-Baden: Ergon Verlag, 2018), 241-250.

38 Gérard Kahn, "Schweizerische Korczak Gesellschaft. Association Suisse des Amis du Dr. Janusz Korczak," in Handbuch Vereine der Reformpädagogik, ed. Maren Gronert and Alban Schraut (Baden-Baden: Ergon Verlag, 2018), 251-256.

39 I have used the translated term chosen by Barbara Engemann. Cp. Barbara Engemann, "Common Effort and Common Joy. Report on the activity of the Janusz Korczak Research Team of the Commission for the History of Education and Schools, the Academy of Pedagogical Sciences of the German Democratic Republic," Bulletin of the Janusz Korczak International Association, no. 5-6 (January-June, July-December, 1982), 10-12.

40 Barbara Engemann-Reinhardt, "Mein Weg mit Korczak - Berlin, Warschau und Düsseldorf", 33-34.

${ }^{41}$ Barbara Engemann-Reinhardt, "Günter Schulze (1925-2010)," Korczak-Bulletin 20 (2011): 44-45.

42 Engemann-Reinhardt described, that the employees of the publishing house had access to the Börsenblatt für den Deutschen Buchhandel, so they could read: Hartmut von Hentig, "Janusz Korczak oder Erziehung in einer friedlosen Welt," in Börsenblatt für den Deutschen Buchhandel, Frankfurter Ausgabe, October 10, 1972, 2345-2354; Rudolf Gönner, "Janusz Korczak - der polnische Pestalozzi," in Börsenblatt für den Deutschen Buchhandel, Sondernummer zur Frankfurter Buchmesse, September 6, 1972, 4-10; Barbara Engemann-Reinhardt, "Mein Weg mit Korczak - Erfahrungen einer Sammlerin", 12-13. 
written by Lenin's wife, Nadeschda Krupskaja (1869-1939) in 1922, paved the way for the first East-German edition of Korczak's works in 1975 in Berlin $^{43}$. From 1978, Korczak research in East Berlin increasingly gained international reputation. On the occasion of Korczak's 100th anniversary the Academy of Educational Sciences of the GDR organized a colloquium of its own in Berlin. A few months later, five delegates from East Germany ${ }^{44}$ joined the International Symposium in Warsaw, where they met their colleagues from West Germany.

When the Janusz Korczak International Association was founded by Korczak experts from 20 different countries, one representative from each of the two German states was elected to the board: Dauzenroth from West Germany and Engemann from East Germany. ${ }^{45}$

Even before the official founding of the Janusz Korczak Research Team, Schulze and Engemann were the persons to contact for research about Korczak in East Germany. ${ }^{46}$ This was especially the case after the publication of the first book on Korczak in 1975 in the GDR, which was followed by another three publications in 1978 and 1979. ${ }^{47}$ In these years, cooperations started with educational institutions, who wanted to obtain the name Janusz Korczak for their school. With the help of the Janusz Korczak Research Team in Berlin the school for special education in Halle received its current name: "Janusz-Korczak-School". Many other schools followed, e.g. in Finsterwalde (1978), Neulewin (1979), and Berlin (1980). ${ }^{48}$

43 Barbara Engemann-Reinhardt, "Mein Weg mit Korczak - Erfahrungen einer Sammlerin", 12; Günter Schulze, ed., Janusz Korczak. Die Liebe zum Kind, eine Auswahl aus seinen Schriften (Berlin: Union-Verlag, 1975).

44 Werner Lindner, Günter Schulze, Bruno Schymon, Hanka Daube, Barbara Engemann, cp. Barbara Engemann-Reinhardt, "Mein Weg mit Korczak - Berlin, Warschau und Düsseldorf", 37.

45 Ibid., 36-39.

46 This suggests an inquiry by letter from Dauzenroth to Schulze, dated July 6, 1977 , in which he asked about the plans on the occasion of the $100^{\text {th }}$ birthday of Korczak in East Germany, cp. Korczak Collection, ULBD, Slg. 15/Dok/129, unpaginated.

47 Janusz Korczak, Wenn ich wieder klein bin: eine Auswahl aus seinen Schriften, ed. Günter Schulze, trans. Ilka Boll (Berlin: Union Verlag, 1978); Janusz Korczak, König Maciuś der Erste. Roman in zwei Teilen für Leser jeden Alters, ed. Günter Schulze, trans. Monika Heinker (Leipzig and Weimar: Kiepenheuer, 1978); Marek Jaworski, Janusz Korczak: aufopferungsvolle Liebe zum Kind (Leipzig: Hirzel, 1979).

48 Prior to these, there already existed a "Korczak School" in Wolgast, East Germany, since 1974. 
In 1980, the Janusz Korczak Research Team was affiliated to the Academy of Pedagogical Sciences, which was subordinated to the Ministry of National Education of the GDR. This not only earned it a very long name ${ }^{49}$, but also the need for political justification vis-à-vis the superior state organisation. At least in official pronouncements of the society, Korczak became part of the state doctrine of the GDR. Thus, Korczak and his pedagogy were justified as the legacy of a "Polish anti-fascist martyr" ${ }^{50}$, as Günter Schulze pointed out in his lecture on the foundation of the association on September 12, 1980. ${ }^{51}$

In retrospective Barbara Engemann described a balancing act between political adaptation, on the one hand, and reform-pedagogical freedom in a protected space, on the other hand. ${ }^{52}$

However, political and ideological appropriation of Korczak's pedagogical work is not only a phenomenon of Korczak's reception in the GDR many other examples can be found ${ }^{53}$, whose systematic analysis is still pending.

49 "Forschungsgemeinschaft Janusz Korczak bei der Kommission für Erziehungs- und Schulgeschichte der Akademie der Pädagogischen Wissenschaften der DDR".

50 Cp. Günter Schulze, "Vom Sinn und Ziel der Korczak-Forschung in der DDR," in Jahrbuch für Erziehungs- und Schulgeschichte 22 (1982) 77-82, 77: "Bei der Weiterentwicklung der kommunistischen Erziehung in Theorie und Praxis, (...) haben die Beschäftigung [sic] mit dem Leben und Sterben dieses bedeutenden Menschen und das Studium des Vermächtnisses dieses polnischen antifaschistischen Märtyrers eine wichtige Quelle unserer marxistisch-leninistischen Pädagogik erschlossen."

51 Ibid. There are many other examples, that show early attempts to justify East-German Korczak studies in the light of the state doctrine of the GDR.

52 Barbara Engemann-Reinhardt, "Mein Weg mit Korczak - Berlin, Warschau und Düsseldorf”, 41: "Die ,Angliederung' an die APW schützte uns zwar auf der einen Seite vor Widersachern, war aber gleichzeitig 'Richtschnur', da sie das Sprachrohr des Ministeriums für Volksbildung war.”, cp. Barbara Engemann-Reinhardt, "In der DDR für Korczak arbeiten - Kurze Rückschau aus persönlicher Sicht," in Korczak Bulletin 16, no. 2 (2007): 53; Barbara Engemann-Reinhardt, "Zur Bedeutung der Pädagogik Janusz Korczaks in gesellschaftlich und pädagogisch totalitären Strukturen, dargestellt am Beispiel der ehemaligen DDR," in Janusz Korczak und die Kinderrechtegestern, heute, morgen, ed. Sigrid Tschöpe-Scheffler and Winfried Kaminski (Eitorf: gata, 2002), 85-101.

53 In 1982, on the occasion of the 40 ${ }^{\text {th }}$ anniversary of Korczak's death, the Polish-Jewish Janusz Korczak Lodge published in two different German newspapers (Süddeutsche Zeitung; Die Welt, August 05, 1982) an appeal against terrorism of the Palestine Liberation Organisation (PLO). Cp. Korczak Collection, ULBD, Slg. 15/Dok/125. 
The sister organisations in East and West did not only differ as to their organisational form. The membership of the Research Team and the scope of its duties were also defined differently. Thus, the directors of the Janusz Korczak institutions in East Germany usually became members of the Research Team. Therefore, the aim of the Research Team was not only to advise the teaching staff, but to keep up Korczak's memory and pedagogical principles at their respective institutions. An exchange of experiences between the different Korczak schools was one of the declared objectives of the biannual consultative meetings, which took place in the various Korczak institutions or at the Polish Information and Cultural Centre in Berlin. These meetings were regularly attended by two colleagues from the Polish Korczak Committee, who were not only invited but whose travel expenses were also financed by the research team or the responsible ministry. ${ }^{54}$ Until 1990, a total of 14 institutions in East Germany were given the name Janusz Korczak. ${ }^{55}$

\section{International studies and cooperations: The international bibliography}

Beyond pedagogical conferences international research cooperations were established in the 1980s. A characteristic example was the international Janusz Korczak bibliography, which was conceptualised and scientifically coordinated by Aleksander Lewin (1915-2002), head of the Korczak Research Centre (Zakład Spuścizny Pedagogicznej Janusza Korczaka) at the Instytut Badań Pedagogicznych in Warsaw. Lewin worked with Korczak in the Warsaw orphanage Dom Sierot in 1937-1939 and in later years tried to combine Korczak's pedagogical approaches with those of the Soviet pedagogue Anton Semënovič Makárenko (1888-1939). After running a Polish children's home in his Soviet exile during WW II, he returned to the Warsaw orphanage. He became not only a recognised educator, author of numerous pedagogical writings and professor at the Polish Teachers' Union Higher School of Education in Warsaw ${ }^{56}$ but also a leading figure in Korczak research in Poland.

54 Barbara Engemann-Reinhardt, "Mein Weg mit Korczak - Berlin, Warschau und Düsseldorf”, 42; Korczak Collection, ULBD, Slg. 15/Dok/111, unpaginated.

55 Korczak facilities in Berlin and the new federal states; personal list of Barbara Engemann-Reinhardt.

56 His multifacetted pedagogical work also included training for educators in a communist youth detention centre in Jaworzno. Daniel Bóckowski, "Janusz Korczak, 
The Korczak Research Centre in Warsaw planned the edition of the international bibliography in five volumes - listing primary and secondary literature within authors lifetime (1896-1942) in Polish (vol. 1), furthermore a collection of Korczak literature since 1943 in German (vol. 2), in Polish (vol. 3), in Hebrew (vol. 4) and in English and French (vol. 5). Several national Korczak committees as well as members of the International Korczak Association contributed to these volumes: They were asked to create their own national Korczak bibliography under certain unified editorial guidelines in order to sort and make visible the Korczak literature for further international research. ${ }^{57}$ Barbara Engemann, for example, edited a bibliography of Korczak books - published in the GDR between 1949 and 1987 - in 1988. ${ }^{58}$ For the West-German Korczak literature the "Giessener Korczak-Bibliographie" already existed since 1980, which was itself created with the help of the International Korczak Society, the French association "Les Amis du docteur Janusz Korczak" as well as Shimon Sachs from Israel. ${ }^{59}$ In cooperation with Erich Dauzenroth (University Gießen) and Friedhelm Beiner (University Wuppertal) and funded by a German research grant from the Inter Nationes foundation in Bonn ${ }^{60}$, the distribution of the bibliographic volumes was exclusively planned with the German Dieck publishing house in Heinsberg ${ }^{61}$. The first volume ${ }^{62}$

Aleksander Lewin and the Polish orphanage in Monetna in the Urals," Studia z Dziejów Rosji i Europy Środkowo Wschodniej 52, no. 3, special issue (2017): 127-136.

57 Aleksander Lewin, "Przedmowa," in Janusz Korczak Bibliografia polska 1943-1987, ed. Aleksander Lewin, 7-8.

58 Barbara Engemann, ed., Bibliographie der 1949-1987 von und über Janusz Korczak in der DDR erschienenen Publiaktionen (Berlin: Forschungsgemeinschaft Janusz Korczak bei der Kommission für deutsche Erziehungs- und Schulgeschichte der Akademie der Pädagogischen Wissenschaften der DDR, 1988). The first book dated from 1975: Günter Schulze, ed., Janusz Korczak. Die Liebe zum Kind.

59 Erich Dauzenroth, Adolf Hampel, Giessener Korczak-Bibliographie: Auswahl (Gießen: Justus-Liebig-Universität, 1980), 1.

60 This foundation existed from 1952-2000, its main purpose was the distribution of German cultural assets abroad. In 2000, the Foundation merged with the Goethe Institut, which temporarily bore the name "Goethe Institut Inter Nationes".

${ }^{61} \mathrm{Cp}$. Pressedienst Justus-Liebig-Universität Giessen: "Internationale KorczakBibliographie", January 1, 1989, Europa-Universität Viadrina Frankfurt (Oder), Karl Dedecius Archiv, Erich Dauzenroths Nachlass und Janusz-Korczak-Kollektion, Sign. DE 1-2-3-111.

62 Aleksander Lewin, ed., Janusz Korczak Bibliografia 1896-1942. 
was based on the bibliographic work, which started in the 1960s and left unfinished by the pedagogue Matylda Temkin (1903-1970), who first met Korczak in the early 1920 s at the age of 19 and worked as a trainee ${ }^{63}$ in a children's home co-directed by Korczak. ${ }^{64}$ After studying education in Belgium and gaining her doctorate, she was deputy head of Dom Sierot in the late 1930s. She emigrated to the Soviet Union in 1939, from where she returned to Poland and the Warsaw orphanage in 1956, becoming an active member of the Polish Korczak committee. Temkins work was continued and finally completed by an editorial team at the Korczak Research Centre in Warsaw, especially by Marta Ciesielska and Maria Bronikowska. ${ }^{65}$ The first volume lists 887 publications of Korczak in chronological order (1896-1942) and adds a list of another 113 letters, unpublished texts and other documents (1915-1942); furthermore, it contains the mainly Polish secondary literature on Korczak. The preface of the first volume as well as the table of contents, printed in four languages (Polish, English, Russian, and German) can be regarded as an indicator of the international claim of this Korczak bibliography. Finally, only three of the originally planned five volumes could be published. ${ }^{66}$

63 Attached to the orphanage was a burse, whose members were also looked after by Korczak and Wilczyńska. Temkin worked and lived there in the early years as a bursist.

64 Temkin herself ran a boarding school in 1927-1930 and temporarily covered Wilczyńska as head of Dom Sierot (1938-1939). In 1939 she fled to the Soviet Union, where she lived under the most difficult conditions until her return to Poland in 1956. Returning to Warsaw, she worked again as pedagogue at the former orphanage Nasz Dom and was one of the active members of the Korczak Committee. Cp. Erich Dauzenroth and Friedhelm Beiner, eds., Dokumente aus den Kriegs- und Ghetto-Jahren, Janusz Korczak. Sämtliche Werke, vol. 15 (Gütersloh: Gütersloher Verlagshaus, 2005), 239; Matylda Temkin, "Der Praktiker, der Forscher, der Neuerer," in Janusz Korczak in der Erinnerung von Zeitzeugen: Mitarbeiter, Kinder und Freunde berichten, ed. Friedhelm Beiner and Silvia Ungermann, trans. Nora Koestler (Gütersloh: Gütersloher Verlagshaus 1999), 254-258, 563.

65 Mentioned by name were furthermore Maria Falkowska, Marzena Kostka, Danuta Słowicka and Anna Wernik, cp. Aleksander Lewin, Janusz Korczak Bibliografia 1896-1942, 15-16.

66 Friedhelm Beiner, Erich Dauzenroth, Elisabeth Lax, eds., Janusz Korczak Bibliographie. Quellen und Literatur (dt.) 1943-1987 (Heinsberg: Agentur Dieck, 1987); Aleksander Lewin, Marzena Kostka, eds., Janusz Korczak. Bibliografia Publikacji Janusza Korczaka I o Januszu Korczaku W Polsce 1943-1987 (Heinsberg: Agentur Dieck, 1988). 


\section{Conclusion and perspective}

In the last decade of the Cold War, Korczak associations were founded in both German states under the umbrella of completely different institutions and under divergent political auspices, which essentially shaped the kind of memory process in the respective contemporary context. The intentions and strategies of establishing, institutionalising and professionalising the respective Korczak associations were based on different political approaches, which led to equally different forms of memory.

The East German association was in close contact and exchange with pedagogical "Korczak" institutions. Their affiliation to the Academy of Pedagogical Sciences led to both greater political control and a stronger ideological appropriation of Korczak, including the politically expected cooperations with their Polish colleagues. However, their membership in the International Korczak Association in Warsaw opened up the opportunity of international cooperation that extended beyond the Eastern Bloc countries and facilitated an international exchange. Barbara Engemann described her work in the International Association as a "window to the world and a bridge to other countries" (trans. A. OH.). ${ }^{67}$

The West German association was more committed towards the academic discourse at the faculties of education at the Justus-Liebig-University in Gießen and the University of Wuppertal. Erich Dauzenroth's personal contacts to Poland in particular enabled him to play an essential role in later German-Polish research cooperations. There is much evidence, that the researchers themselves viewed their studies as reconciliation work between nations. Its representatives repeatedly emphasised their selfimage as "international work of reconciliation" (trans. A. OH.). ${ }^{68}$ Therefore,

67 Quoted from Nina Mueller, Gertrud Pickhan, "Pons inter nationes", 693: "Fenster zur Welt und Brücke zu anderen Ländern."

${ }^{68}$ Cp. Friedhelm Beiner, ed., 'Auf dass nichts in Vergessenheit gerät'. Zeugen und Zeugnisse für Janusz Korczak (Gießen: Institut für Bildungsforschung und Pädagogik des Auslands, Justus-Liebig-Universität, 1989), 3: “...die deutsche KorczakGesellschaft begreift sich nicht nur als eine wissenschaftliche Gesellschaft, sie begreift sich als ein internationales Versöhnungswerk."; Ibid, 7: "Wir Korczakianer jedenfalls leben und arbeiten für diese Vision einer Freundschaft unter Menschen und Völkern...”; Ibid, 5: "Die Mitglieder der Korczak-Gesellschaft begnügen sich nicht mit dem Gedenken an das Vermächtnis Korczaks allein. Dieses Vermächtnis verpflichtet sie, sich für eine Welt einzusetzen, in der man in Frieden, Sicherheit und Ehre leben kann." 
members of the Korczak society considered the remembrance of Janusz Korczak against the background of the Holocaust and German guilt. ${ }^{69}$

Nevertheless, the German-German neighbours in this field of research remained largely separated during the Cold War - this changed only slowly even after 1989.

The German reunification marked the end of the Janusz Korczak Research Team. Its long-standing members were referred to the West German society. A first joint conference was held in Berlin in 1991, which elected Beiner as its first and Engemann as its second chairman and chairwoman, respectively. Nevertheless, the difficulties of the reunification process between the two German states did not leave the Korczak movement unaffected. ${ }^{70}$ The edition of the 16 volumes comprising collected works of Korczak (1996-2010) ${ }^{71}$, which was based on a German translation of the complete Polish edition, did not involve any former East German Korczak researcher.

A detailed history of Korczak's reception, even beyond the history of German Korczak memory, still needs to be written: Thomas Söderqvist described the different perspectives and motivations of biographers ranking from personal fascination with a person to professional and disciplinary interests. Furthermore, biographies of outstanding personalities play an important role in moral education: they can serve as a model for a good and fulfilled life. ${ }^{72}$ This aspect is particularly striking in the case of Korczak, who became known above all as a moral authority: ${ }^{73}$ His mar-

${ }^{69} \mathrm{Cp}$. Friedhelm Beiner, "Ein Pädagogik-Konzept auf dem Prüfstand," in Ergänzungsband, 9-10, 10: "Die Edition dieses Bandes ist für mich nicht nur ein Beitrag zur Überlieferung wichtiger authentischer Erfahrungen und Erlebnisse, sondern auch mein Dank an Korczak-Schüler und -Zeitgenossen, die mir eine freundschaftliche Hand reichten - über Gräber und Aschefelder hinweg."

70 A characteristic example was the competition between two Korczak-schools in East and West Berlin. Cp. Barbara Engemann-Reinhardt, "Mein Weg mit Korczak Berlin, Warschau und Düsseldorf", 45-46.

71 Beiner, F, Dauzenroth E (eds.) (1996-2010) Janusz Korczak. Sämtliche Werke, vols. $1-16$ and 2 supplementary vols.

$72 \mathrm{Cp}$. Thomas Söderqvist, "Wissenschaftsgeschichte à la Plutarch. Biographie über Wissenschaftler als tugendethische Gattung," in Biographie schreiben, ed. Hans Erich Bödecker (Göttingen: Wallstein, 2003, 287-325, 300: “(...) daß Lebensgeschichten Antworten geben auf die klassische ethische Frage: Was heißt es, ein gutes und erfülltes Leben zu führen?"

73 Cp. Andreas Flitner, Reform der Erziehung. Impulse des 20. Jahrhunderts (München and Zürich: Piper, 1992), 48; Kristina Schierbaum, Janus Korczak, der Brückenbauer, 1; 
tyrdom is omnipresent in the popular as well as in the academic discourse. However, it remained unclear what role Korczak's memory plays in moral education in East- and West-Germany against the background of Holocaust remembrance.

Furthermore, the question arises as to how scientific biographical analyses relate to existing popular clichés about Korczak. Do they serve to debunk the clichés, as Bernadette Bensaude-Vincent asks in the context of scholars' biographies? Or can they serve as mediators between memory and the history of science? ${ }^{74}$ These questions have to be explored in future investigations.

This article aims to encourage reflections on Korczak and his remembrance in the light of competing communities of memory. Their institutional structures, their biographical and bibliographical research on Korczak's life and work and, last but not least, their contacts to contemporary witnesses and colleagues of different disciplines and nationalities with diverse commemorative intentions, motivations and practices have significantly shaped the Korczak image in the public.

However, many witnesses and therefore personal memories will no longer be alive and accessible. So without these ressources, the question remains, as to how the history of Korczak's memory and culture of remembrance will be shaped in the years to come.

\section{Vācu un poḷu zinātniskā sadarbība sadalītajā Vācijā: Januša Korčaka apvienības Austrumvācijā un Rietumvācijā kopš 20. gadsimta 70. gadiem}

\section{Kopsavilkums}

Poḷu un ebreju izcelsmes pediatrs, pedagogs un rakstnieks Janušs Korčaks (Janusz Korczak, 1878/1879(?)-1942) izpelnījās ievērību Vācijā tikai daudzus gadus pēc viņa nāves Treblinkas nāves nometnē 1942. gadā. Vācijas sašķeltība kḷuva par iemeslu divu atsevišķu Vācijas akadēmisko apvienību izveidei un attīstībai kopš 20. gadsimta 70. gadu beigām.

$74 \mathrm{Cp}$. Bernadette Bensaude-Vincent, "Biographies as Mediators between Memory and History in Science," in The History and Poetics of Scientific Biography, ed. Thomas Söderqvist (Aldershot: Ashgate, 2007), 173-184. 
Neraugoties uz atšķirīgajiem politiskajiem apstākḷiem, to mērķis bija popularizēt un izplatīt informāciju par Korčaka dzīves gājumu un viņa darbiem. Abas apvienības nodibināja personīgus un akadēmiskus kontaktus un izveidoja sadarbību ar Polijas Korčaka Komiteju, kuras pirmsākumi ir meklējami 1946. gadā, kad Korčaka līdzgaitnieki nodibināja komiteju Korčaka piemiņas godināšanai. Šīs publikācijas mērḳis ir restaurēt abu Korčakam veltīto Vācijas apvienību agrīno zinātnisko sadarbību ar poḷu zinātniekiem un Polijas Korčaka Komiteju.

Vācijas Federatīvajā Republikā galvenās pētniecības stimulētājas bija pedagoğijas fakultātes Gīsenē un Vupertālē, savukārt Vācijas Demokrātiskajā Republikā - pirmais pētniecības centrs izveidojās vien⿳亠gajā tolaik pastāvošajā valsts kontrolētajā mācību grāmatu izdevniecībā (Volk und Wissen - Volkseigener Verlag) Austrumberlīnē. Pagājušā gadsimta 80. gadu sākumā jauno apvienību darba centrā bija Korčaka darbības biogrāfiski un bibliogrāfiski pētījumi. Šos pētījumus gan Polijā, gan Rietumvācijā iedvesmoja un veicināja tolaik vēl dzīvi esošie Korčaka līdzgaitnieki un viņu personīgie kontakti ar atsevišşiem Korčaka apvienību biedriem. Daudzie Korčaka starptautiskās bibliogrāfijas apkopojumi ir lieliska liecība tam, kā, aculiecinieku liecībām caurvijot dažādus piemiṇas slāṇus, notika viṇa darbības pētījumi.

Atslēgvārdi: Janušs Korčaks, Korčaka apvienības, aukstais karš, vācu un poḷu pētnieku sadarbība, līdzgaitnieki, piemiṇas izpēte.

\footnotetext{
Anne Oommen-Halbach

Dr., Medicīnas vēstures, fílozofijas un ētikas katedra, Heinriha Heines Universitāte Diseldorfā, Vācija /

Dr., Department of the History, Philosophy and Ethics of Medicine, Heinrich-Heine-University Düsseldorf, Germany
} 